\title{
PERUBAHAN TUTUPAN LAHAN TERHADAP DEBIT BANJIR MENGGUNAKAN MODEL REGRESI LINIER BERGANDA SUB DAS MUSI HULU KABUPATEN MUSI RAWAS
}

\author{
Okma Yendri, ${ }^{1}$ Andi Wahyudi ${ }^{2}$ Gusta Gunawan ${ }^{3}$ \\ ${ }^{1}$ Program Studi Teknik Sipil Universitas Musi Rawas, Indonesia \\ Email:okmayendri@gmail.com \\ ${ }^{2}$ Program Studi Teknik Sipil Universitas Musi Rawas, Indonesia \\ Email: andiwahyudii@gmail.com \\ ${ }^{3}$ Program Studi Teknik Sipil Universitas Musi Rawas, Indonesia \\ Email:gustagunawan@gmail.com
}

\begin{abstract}
ABSTRAK
Perubahan lahan yang digunakan akan mempengaruhi debit banjir di DAS. Tujuan dari penelitian ini adalah untuk mengetahui dampak lahan yang digunakan untuk berubah pada debit banjir di DAS hulu Musi Musi Rawas. Data yang dibutuhkan berupa data curah hujan. Tanah tersebut menggunakan data dan peta topografi. Data curah hujan digunakan data curah hujan harian yang dicatat di stasiun Kungku SPAS. Data curah hujan harian ditransformasikan menjadi intensitas curah hujan per jam 'Metode Mononabe'. Berdasarkan hasil penelitian tutupan lahan mengubah debit banjir dengan menggunakan model regresi linier berganda dengan variabel bebas yaitu tutupan lahan perkebunan kopi, semak, campuran kebun, padi, perkebunan rakyat, perkebunan besar dan pemukiman. Sementara, variabel yang tidak independen adalah banjir yang terjadi karena perubahan tutupan lahan. Berdasarkan hasil analisis data yang dilakukan pada Spa hulu sub-DAS Kungku Musi Musi Rawas menggunakan SPSS terlihat bahwa perubahan tutupan lahan sangat mempengaruhi periode kembali debit banjir pada waktu tertentu. Jumlah puncak buangan yang terjadi dalam 2 tahun ke depan = 12:23 $\mathrm{m3} /$ detik 2 tahun, 5 tahun berikutnya = 16,63 $\mathrm{m} 3 /$ detik, 10 tahun berikutnya $=20: 56 \mathrm{m3} /$ detik, 25 tahun berikutnya $=26,89 \mathrm{m3} /$ detik, 50 tahun berikutnya $=32,75 \mathrm{m3} /$ detik dan 100 tahun berikutnya $=39,75 \mathrm{m3} /$ detik.
\end{abstract}

\section{Kata Kunci: Penggunaan Lahan, Banjir Debit, Metode Rasional.}

\begin{abstract}
The changes in land used will affect the flood discharge in the watershed. The purpose of this study was to determine the impact of land used to changed on the flood discharge in the watershed upstream sub - watershed Musi Musi Rawas. The data required in the form of rainfall data. The land used data and topographic maps. Rainfall data is used daily rainfall data recorded at stations Kungku SPAS. Daily rainfall data was transformed to hourly rainfall intensity 'Mononabe method'. Based on the results of research the land cover changed the flood discharge by using a multiple linear regression model with independent variable are coffee plantation land cover, shrubs, garden mix, rice, smallholder plantations, large estates and settlements. While, variable aren't independent is flooding that occurs because of changes in land cover. Based on the results of data analysis performed on the sub-watershed upstream Spas Kungku Musi Musi Rawas using SPSS it was seen that changes in land cover greatly affects the return period flood discharge at a particular time. The number peak discharge that occurs in the next 2 years $=12: 23 \mathrm{~m} 3 / \mathrm{second} 2$ years, next 5 years $=16.63 \mathrm{m3} / \mathrm{second}$, next 10 years $=20.56 \mathrm{m3} / \mathrm{second}$, next 25 years $=26.89 \mathrm{~m} 3 / \mathrm{second}$, next 50 years $=32.75 \mathrm{~m} 3 / \mathrm{second}$ and next 100 year $=39.75 \mathrm{~m} 3 / \mathrm{second}$.
\end{abstract}

Keywords : The land Use, Debit Flood, Rational Method. 


\section{Pendahuluan}

Perubahan iklim merupakan tantangan paling serius yang dihadapi dunia, perubahan iklim semakin nyata terjadi dan mempengaruhi berbagai sisi kehidupan, baik yang bersifat individual atau domestik maupun sampai sektor pembangunan berskala global. Di sisi lain, semakin disadari bahwa percepatan terjadinya perubahan iklim diawali oleh keputusan dan perilaku manusia yang kemudian terakumulasi secara massif hingga mengubah unsur-unsur cuaca, terutama suhu, sehingga menyebabkan fenomena pemanasan global. (Pusat Riset Perubahan Iklim UI, 2012).

Dampak dari pemanasan global salah satunya adalah curah hujan yang tinggi, seperti yang terjadi di daerah catchments area Sub DAS Musi Hulu SPAS Kungku Kabupaten Musi Rawas. Akibat tingginya intensitas curah hujan yang terjadi mengakibatkan banjir.

Perubahan tutupan lahan dapat berdampak negatif bagi Kabupaten Musi Rawas karena dengan adanya perubahan tersebut mengakibatkan berkurangnya lahan resapan dan mengakibatkan limpasan menjadi besar. Secara khusus, perubahan tata guna lahan berdampak kepada banjir dan genangan yang cenderung meningkat dari waktu ke waktu seperti yang telah di teliti oleh (Suroso dan hery, 2001), pada daerah kawasan DAS Banjaran yang meneliti tentang pengaruh perubahan tata guna lahan terhadap debit banjir daerah aliran sungai banjaran . Oleh karena itu, penelitian sejenis perlu dilakukan di kawasan Sub DAS Musi Hulu SPAS Kungku Kabupaten Musi Rawas karena dampak perubahan tata guna lahan telah mengakibatkan debit banjir, karena karakteristik DAS ini berbeda dengan DAS yang lain.

Tujuan dari penelitian ini adalah untuk mengetahui dampak perubahan tata guna lahan terhadap debit banjir pada daerah aliran sungai di sub DAS Musi Hulu Kabupaten Musi Rawas.

\section{Daerah Aliran Sungai}

Daerah Aliran Sungai (DAS) adalah suatu wilayah daratan yang secara topografik dibatasi oleh punggung-punggung gunung yang menampung dan menyimpan air hujan untuk kemudian menyalurkannya ke laut melalui sungai utama. (Asdak, 20050.

DAS mempunyai bentuk yang bermacammacam berdasarkan bentuk topografi dan geologinya. Secara garis besar bentuk DAS dapat dikelompokkan menjadi 3 bagian yaitu: Bentuk memanjang, bentuk melebar dan bentuk kipas. Bila lebih detail pengelompokkannya maka bentuk DAS bisa saja merupakan gabungan dari ketiga kelompok tersebut, misalnya bentuk suatu DAS memanjang dan sekaligus juga melebar. Gambar 1 menunjukan bentuk DAS tersebut.

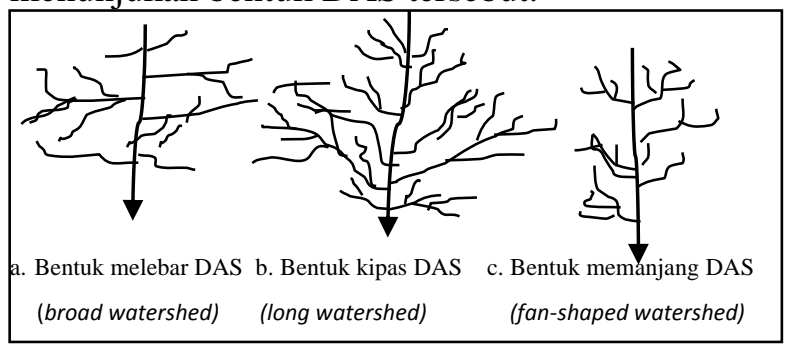

Gambar 1. Bentuk sederhana DAS (Kinori dan Mevorach, 1984).

\section{Tata Guna Lahan}

Tata guna lahan dan pengembangan dapat dikatakan sebagai masalah utama dalam pemenuhan infrastruktur. Dalam pemenuhan infrastruktur, selain manajemen infrastruktur, manajemen mengenai tata guna lahan juga harus diperhatikan. Dalam aspek lingkungan, lahan bukan saja memberikan wadah fisik kedudukan sistem produksi, tetapi juga memberi masukan dan menerima hasil serta memperbaiki kerusakan sistem produksi.

Sehingga setiap jenis penggunaan lahan dapat mencirikan kualitas penggunaan lahannya, dan etika lahan memberi tanda-tanda kerusakan, jenis penggunaan lainnya siap menggantikanya. Begitu juga sebaliknya, apabila lahan memberikan

\section{Tinjaun Pustaka}




\section{Volume 12 Nomor 2, Agustus 2019}

manfaat sosial, maka sebaiknya penggunaannya tetap dipertahankan (Nugroho \& Dahuri, 2004).

\section{Debit Banjir Rencana}

Metode untuk mendapatkkan debit banjir rencana dapat menggunakan metode berikut:

\section{a. Metode Rasional}

Menurut Wanielista (1990) metode Rasional adalah salah satu dari metode tertua dan awalnya digunakan hanya untuk memperkirakan debit puncak (peak discharge). Ide yang melatarbelakangi metode Rasional adalah jika curah hujan dengan intensitas (I) terjadi secara terus menerus, maka laju limpasan langsung akan bertambah sampai mencapai waktu konsentrasi (Tc). Waktu konsentrasi (Tc) tercapai ketika seluruh bagian DAS telah memberikan kontribusi aliran di outlet.

Laju masukan pada sistem (IA) adalah hasil dari curah hujan dengan intensitas (I) pada DAS dengan luas (A). Nilai perbandingan antara laju masukan dengan laju debit puncak (Qp) yang terjadi pada saat (Tc) dinyatakan sebagai run off coefficient (C) dengan $(0 \leq \mathrm{C} \leq$ 1) (Chow, 1988).

Hal di atas diekspresikan dalam formula Rasional sebagai berikut ini (Chow, 1964) :

$\mathrm{Q}=0,277 \mathrm{C}$ I A

Keterangan :

$\mathrm{Q}$ : debit puncak ( $\left.\mathrm{m}^{3} / \mathrm{dtk}\right)$

$\mathrm{C}$ : koefisien run off, tergantung pada karakteristik DAS (tak berdimensi)

I : intensitas curah hujan, untuk durasi hujan

(D) sama dengan waktu konsentrasi (Tc) (mm/jam)

A : luas DAS $\left(\mathrm{km}^{2}\right)$

Konstanta 0,277 adalah faktor konversi debit puncak ke satuan ( $\left.\mathrm{m}^{3} / \mathrm{dtk}\right)$ (Seyhan, 1990). Beberapa asumsi dasar untuk menggunakan formula Rasional adalah sebagai berikut (Wanielista, 1990) : a. Curah hujan terjadi dengan intensitas yang tetap dalam satu jangka waktu tertentu, setidaknya sama dengan waktu konsentrasi.

b. Limpasan langsung mencapai maksimum ketika durasi hujan dengan intensitas yang tetap, sama dengan waktu konsentrasi.

c. Koefisien run off dianggap tetap selama durasi hujan.

d. Luas DAS tidak berubah selama durasi hujan.

\section{Intensitas hujan}

Perhitungan debit banjir dengan metode rasional memerlukan data intensitas curah hujan. Intensitas curah hujan adalah ketinggian curah hujan yang terjadi pada suatu kurun waktu di mana air tersebut terkonsentrasi. Intensitas curah hujan dinotasikan dengan huruf I dengan satuan mm/jam. (Loebis, 1992).

Durasi adalah lamanya suatu kejadian hujan. Intensitas hujan yang tinggi pada umumnya berlangsung dengan durasi pendek dan meliputi daerah yang tidak sangat luas. Hujan yang meliputi daerah luas, jarang sekali dengan intensitas tinggi, tetapi dapat berlangsung dengan durasi cukup panjang.

Sri Harto (1993) menyebutkan bahwa analisis IDF memerlukan analisis frekuensi dengan menggunakan seri data yang diperoleh dari rekaman data hujan. Jika tidak tersedia waktu untuk mengamati besarnya intensitas hujan atau disebabkan oleh karena alatnya tidak ada, dapat ditempuh cara-cara empiris dengan mempergunakan rumus-rumus eksperimental seperti rumus Talbot, Mononobe, Sherman dan Ishigur. Dalam penelitian ini intensitas hujan diturunkan dari data curah hujan harian.

Menurut Loebis (1992) intensitas hujan (mm/jam) dapat diturunkan dari data curah hujan harian (mm) empirik menggunakan metode mononobe sebagai berikut:

$2 I=\frac{R_{24}}{24}\left(\frac{24}{\mathrm{t}}\right)^{2 / 3}$ 
3 keterangan :

4 I : intensitas curah hujan ( $\mathrm{mm} / \mathrm{jam})$;

$5 \mathrm{t}$ : lamanya curah hujan (jam);

6 R24 : curah hujan maksimal dalam 24 jam (mm).

\section{Koefisien Limpasan (run off coeffisient)}

Dalam penghitungan debit banjir menggunakan Metode Rasional diperlukan data koefisien limpasan (run off coeffisien). Koefisien limpasan adalah rasio jumlah limpasan terhadap jumlah curah hujan, dimana nilainya tergantung pada tekstur tanah, kemiringan lahan, dan jenis penutupan lahan. Secara garis besar harga koefisien run off ditunjukan dalam Tabel 1.

\section{Tabel 1. Tabel Harga Koefisien Run off}

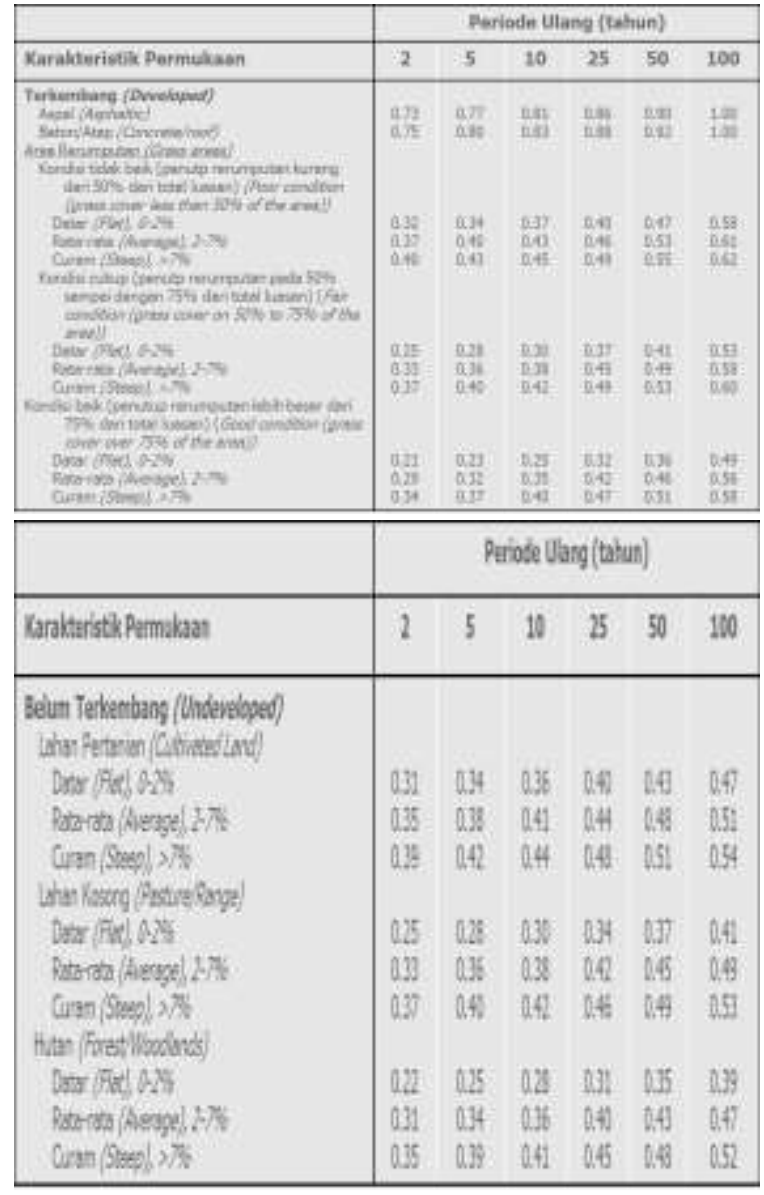

Sumber : Standar Perencanaan Irigasi KP 01,1986.

\section{Metodologi}

\section{Analisis Frekuensi}

Langkah-langkah analisis frekuensi adalah sebagai berikut:

1). Menentukan hujan harian maksimun rerata untuk tiap-tiap tahun data.

2). Menentukan parameter statistik dari data yang telah diurutkan dari besar ke kecil, yaitu : Mean, Standard Deviation, Coeffisient of Variation, Coeffisient of Skewness, Coeffisint of kurtosis.

3). Menentukan jenis distribusi yang sesuai berdasarkan parameter statistik yang ada.

Sifat-sifat khas dari setiap macam distribusi frekuensi (Jayadi, 2000) adalah sebagai berikut:

a. Distribusi Normal

Ciri khas distribusi Normal adalah:
1). Skewness $(\mathrm{Cs}) \cong 0,00$
2). Kurtosis $(\mathrm{Ck})=3,00$
3). $\operatorname{Prob} X \leq(X-S)=15,87 \%$
4). Prob $X \leq-X=50,00 \%$
5). $\operatorname{Prob} X \leq(-X+S)=84,14 \%$

b. Distribusi Log Normal

Sifat statistik distribusi Log Normal adalah:

1). $C s \cong 3 C v$

2). $C s>0$

c. Distribusi Gumbel

Ciri khas statistik distribusi Gumbel adalah:
1). $C s \cong 1,396$
2). $C k \cong 5,4002$

d. Distribusi Pearson III

Sifat statistik distribusi ini adalah:

1). jika tidak menunjukkan sifat-sifat seperti pada ketiga distribusi di atas

2). garis teoritik probabilitasnya berupa garis lengkung

3). Melakukan pengujian dengan Chi-Kuadrat dan Smirnov Kolmogorov untuk mengetahui apakah jenis distribusi yang dipilih sudah tepat. 
a). Uji Smirnov Kolmogorov Pengujian dilakukan dengan mencari nilai selisih probabilitas tiap variat $X i$ menurut distribusi empiris dan teoritik, yaitu disimbolkan dengan $\Delta$. Harga $\Delta \mathrm{i}$ maksimum harus lebih kecil dari $\Delta$ kritik.

b) Uji Chi Kuadrat

Pada dasarnya uji ini merupakan pengecekan terhadap penyimpangan rerata data yang dianalisis berdasarkan distribusi terpilih.

Penyimpangan tersebut diukur dari perbedaan antara nilai probabilitas setiap variat $\mathrm{X}$ menurut hitungan distribusi frekuensi teoritik dan menurut hitungan dengan pendekatan empiris. Rumus yang digunakan adalah (Suroso dan Hery Awan Susanto, 2001).

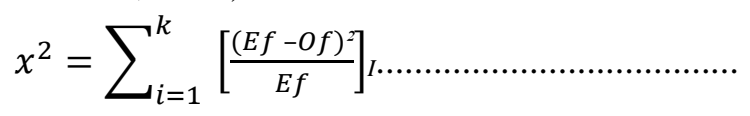

dengan:

$\chi^{2}=$ harga Chi-kuadrat

Ef = frekuensi yang diharapkan untuk kelas i

Of $\quad$ frekuensi terbaca pada kelas i

$\mathrm{K}$ = banyaknya kelas

Harga $\chi^{2}$ harus lebih kecil dari harga $\chi^{2}$ kritik untuk derajat nyata $(\alpha)$ dan derajat kebebasan $(D K)$ tertentu. Umumnya digunakan derajat nyata 5\% dan untuk distribusi Chi-Kuadrat, nilai $D K$ dapat dipakai rumus berikut: (Suroso dan Hery Awan Susanto, 2001) :

$D K=K-(\mathrm{p}+1)$

(3)

dengan:

$\mathrm{DK}=$ derajat kebebasan (number of degree of freedom)

$\mathrm{K}=$ banyaknya kelas (grup)

$\mathrm{P}=$ banyaknya keterikatan (constrain) atau sama dengan banyaknya parameter distribusi

4) Berdasarkan jenis distribusi terpilih dihitung besaran hujan rancangan untuk kala ulang tertentu. Secara umum, persamaan garis teoritik probabilitas untuk analisis frekuensi dapat dinyatakan dengan rumus sederhana sebagai berikut (Haan, 1979):

$X T=X+K_{T} . S \ldots \ldots \ldots \ldots \ldots \ldots \ldots \ldots$

dengan:

$\mathrm{XT}=$ hujan rancangan dengan kala ulang $\mathrm{T}$ tahun, dengan $\mathrm{T}$ adalah $1,2,3$, 4, dan 5 tahun.

$-\mathrm{X}=$ besaran rata-rata

$\mathrm{S}=$ simpangan baku

$K_{T}=$ faktor frekuensi untuk kala ulang $T$ tahun

\section{Data Curah Hujan}

Studi ini memakai data curah hujan harian di stasiun selama 5 tahun terakhir (2008 - 2012) yang diperoleh dari Balai Pengelolaan Daerah Aliran Sungai Musi, BPDAS Palembang.

\section{Hasil dan Pembahasan}

\section{Perhitungan Waktu Konsentrasi (Tc)}

Berdasarkan peta topografi Sub DAS Musi Hulu Kabupaten Musi Rawas dapat diketahui data geometri sungai kungku adalah sebagai berikut:

- $\quad$ Luas Sungai Kungku (A) $=48.50 \mathrm{~km}^{2}$

- Kemiringan sungai $(\mathbf{S}) \quad=400 \mathrm{~m} / \mathrm{m}$

- Panjang sungai $(\mathbf{L}) \quad=21 \mathrm{~km}^{2}$

Waktu konsentrasi (Tc) dapat dihitung berdasarkan persamaan Kirpich (Susanto dan Suroso, 2006) sebagai berikut.

$$
\boldsymbol{T} \boldsymbol{c}=\mathbf{3}, \mathbf{9 7}^{\times} \mathbf{L}^{0,77^{*}} \mathbf{S}^{\mathbf{0 , 3 8 5}}
$$

Dengan, Tc : waktu kosentrasi (jam)

$$
\begin{aligned}
& \mathrm{L} \text { : panjang sungai }(\mathrm{km}) \\
& \mathrm{S} \text { : landai sungai }(\mathrm{m} / \mathrm{m})
\end{aligned}
$$

$$
\begin{aligned}
\text { Sehingga } T c & =3,97 \times(21)^{0,77} \times(400)^{-0,385} \\
& =4.60 \mathrm{jam}
\end{aligned}
$$


Jadi dari hasil perhitungan bahwa waktu konsentrasi yang terjadi pada Sub DAS MUSI HULU SPAS Kungku adalah 4.60 jam.

\section{Tata Guna Lahan Pada Sub DAS Kungku}

Tata Guna Lahan Pada Sub DAS Kungku di Klasifikasikan menjadi 8 (delapan) kelas yaitu: kebun kopi, semak bulukar, kebun campuran, sawah, perkebunan besar, perkebunan rakyat dan pemukiman ( sesuai data yang tersedia dari kantor BPDAS Musi Provinsi Sumatra Selatan). Penggunaan lahan secara rinci dapat di lihat pada Tabel 2 di bawah ini.

Tabel 2. Luas tata guna lahan per tahun

\begin{tabular}{|c|c|c|c|c|c|c|c|c|}
\hline \multirow[b]{2}{*}{ Thlis: } & \multicolumn{7}{|c|}{ LuarPengunuan Lahan (Ba) } & \multirow[b]{2}{*}{ Todal } \\
\hline & $\begin{array}{l}\text { Retros } \\
\text { nkopi }\end{array}$ & $\begin{array}{l}\text { Sertak. } \\
\text { bulakir }\end{array}$ & $\begin{array}{c}\text { Ratuin } \\
\text { catrpur } \\
\text { in }\end{array}$ & Savah & $\begin{array}{l}\text { Perketous } \\
\text { so besar }\end{array}$ & $\begin{array}{l}\text { Perketoris } \\
\text { inrakys. }\end{array}$ & $\begin{array}{c}\text { Petrukim } \\
\text { in }\end{array}$ & \\
\hline 2000 & 697 & 1407 & 1693 & 631 & 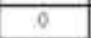 & Q & 422 & 4550 \\
\hline 2009 & 369.9 & 1300 & 1300 & 9 & Q & $\overline{0}$ & 435 & $\begin{array}{c}3404 \\
9\end{array}$ \\
\hline 2010 & 100 & 846 & 675 & 0 & 0 & 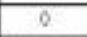 & 448 & 2269 \\
\hline 2011 & $\pi$ & 28.27 & 0 & $\overline{0}$ & 71894 & 400561 & 452 & $\begin{array}{c}5294 \\
8\end{array}$ \\
\hline 2012 & 0 & 2012 & 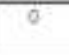 & o & 90035 & 9086.91 & 451 & $\begin{array}{c}9438 \\
4\end{array}$ \\
\hline
\end{tabular}

Sumber : Hasil Perhitungan, 2012

Dari Tabel 2 terlihat bahwa tata guna lahan yang mengalami perubahan yang cukup berarti adalah perkebunan besar, perkebunan rakyat dan pemukiman sedangkan yang mengalami perubahan yang menurun adalah semak belukar dan penggunan lahan yang dulunya ada menjadi tidak ada adalah kebun kopi, kebun campuran dan sawah. Perubahan ini terjadi karena masyarakat di sekitar Sub DAS Musi Hulu tidak menggunakan lahan untuk di gunakan sebagai kebun kopi, kebun campuran dan sawah tetapi di gunakan sebagai perkebunan rakyat dan perkebunan besar. Trend perubahan tata guna lahan didekati mengikuti trend linier sperti terlihat pada Gambar 2 dan 3.

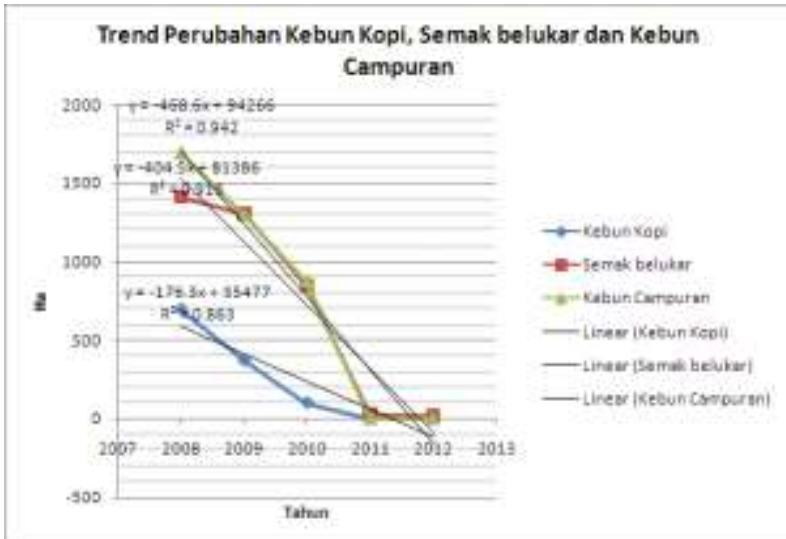

Gambar 2. Trend Linier Perubahan Kebun Kopi, Semak Belukar dan Kebun Campuran

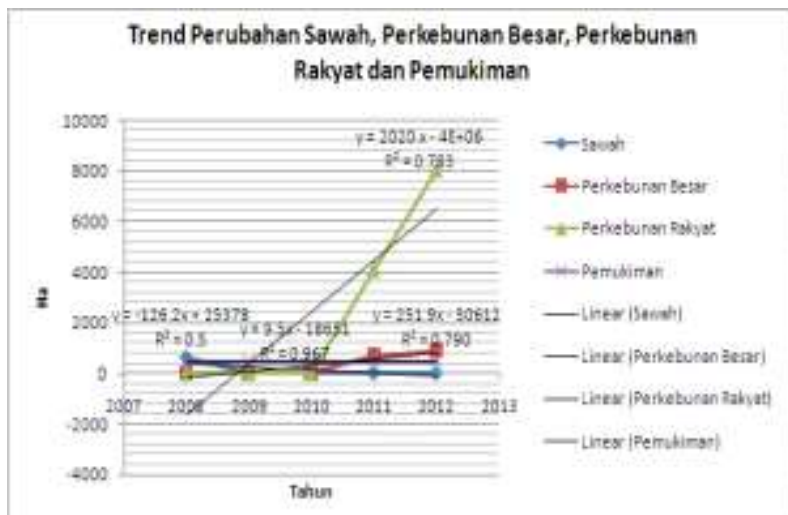

Gambar 3. Trend Linier Perubahan Sawah, Perkebunan Besar, Perkebunan Rakyat dan Pemukiman

\section{Analisis Curah Hujan}

Hujan harian maksimum rerata didekati dengan dengan menggunakan data curah hujan yang ada di stasiun SPAS Kungku yang ada di sub DAS Musi Kabupaten Musi Rawas. Dengan anggapan bahwa curah hujan di stasiun SPAS Kungku dapat mewakili curah hujan di wilayah DAS Musi. Hujan rancangan dengan berbagai kala ulang ditetapkan dengan analisis frekuensi curah hujan maksimum untuk mengetahui jenis distribusi yang dapat mewakili persebaran dari data hujan harian maksimum.

Pada penelitian ini uji statistik dilakukan dengan menggunakan metode Chi Square dan Smirnov Kolmogrov. Analis frekuensi yang dilakukan terhadap data hujan rerata harian 
maksimum yang itu dengan hasil perhitungan sendiri, diperoleh distribusi yang paling cocok mewakili persebaranya adalah Log Perason III. Hal yang ditunjukan dengan nilai $\mathrm{X}^{2}(=0.5) \leq$ $\mathrm{X}^{2}{ }_{\text {kritik }}(=4.878)$ dan $\Delta_{\text {maks }}(=0.17) \leq \Delta_{\text {kritik }}(=0.36)$. Kemudian dilakukan analisis hujan rancangan yang hasilnya yang terlihat dalam Tabel 3 dibawah ini.

Tabel 3. Hujan rancangan berbagai periode ulang

\begin{tabular}{|c|c|c|}
\hline No & $\begin{array}{c}\text { Kala Ulang } \\
\text { (tahun) }\end{array}$ & Hujan Rancangan (mm) \\
\hline 1 & 2 & 12.23 \\
\hline 2 & 5 & 16.63 \\
\hline 3 & 10 & 20.56 \\
\hline 4 & 25 & 26.89 \\
\hline 5 & 50 & 32.75 \\
\hline 6 & 100 & 39.75 \\
\hline
\end{tabular}

Untuk mencari intensitas hujan dalam periode 1 jam dari data curah hujan harian dipakai rumus mononabe. Hasil analisis berupa intensitas hujan dengan durasi dan periode ulang tertentu dihubungkan kedalam sebuah kurva Intensity Duration Frequency (IDF) tampak pada Gambar 4.

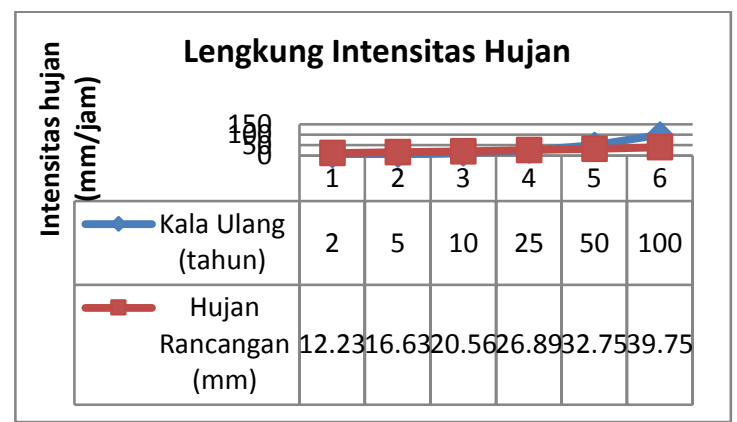

Gambar 4. Kurva Intensitas Hujan

Dari kurva IDF terlihat bahwa intensitas hujan yang tinggi berlangsung dengan durasi yang pendek. Interpretasi kurva IDF diperlukan untuk menentukan debit banjir rencana mempergunakan metode rasional.

\section{Analisis Debit Banjir}

Dalam penghitungan debit banjir menggunakan metode rasional diperlukan data koefisien limpasan (runoff coeffisien). Dalam penelitian ini data koefisien limpasan didapat dari perhitungan sendiri seperti terlihat pada Tabel 4 .
Dengan menggunakan metode rasional didapatkan debit banjir seperti pada Tabel 5 .

Tabel 4. Koefisien Limpasan Sub DAS Musi Hulu SPAS Kungku

\begin{tabular}{|c|c|c|}
\hline No & Tahun & C \\
\hline & 2008 & 0.514 \\
\hline 2 & 2009 & 0.549 \\
\hline 3 & 2010 & 0.547 \\
\hline 4 & 2011 & 0.635 \\
\hline 5 & 2012 & 0.624 \\
\hline
\end{tabular}

Sumber : Hasil Perhitungan, 2012

Tabel 5. Debit Banjir di outlet Sub DAS Musi

\begin{tabular}{|c|c|c|c|c|c|c|}
\hline \multirow{2}{*}{ Tahun } & \multicolumn{5}{|c|}{ Debit Banit $\left(\mathrm{m}^{1} / \mathrm{dt}\right)$} \\
\cline { 2 - 7 } & $T=2$ th & $T=5$ th & $T=10$ th & $T=25$ th & $T=50$ th & $T=100^{2}$ \\
\hline 2008 & 84.78 & 115.25 & 142.50 & 186.36 & 226.96 & 275.49 \\
\hline 2009 & 90.55 & 123.09 & 152.20 & 199.05 & 242.42 & 294.25 \\
\hline 2010 & 90.22 & 122.64 & 151.65 & 198.33 & 241.53 & 293.18 \\
\hline 2011 & 104.74 & 142.37 & 176.04 & 230.24 & 280.39 & 340.34 \\
\hline 2012 & 102.92 & 139.91 & 172.99 & 226.25 & 275.53 & 334.45 \\
\hline
\end{tabular}

Sumber : Hasil Perhitungan, 2012

\section{Analisis Pengaruh Perubahan Tata Guna Lahan Terhadap Debit Banjir}

Dari analisis multiple regression, didapat hubungan antara perubahan tata guna lahan dengan debit banjir, mengikuti persamaan :

$Y=a_{1} \cdot x_{1}+a_{2} \cdot x_{2}+a_{3} \cdot x_{3}+a_{4} \cdot x_{4}+a_{5} \cdot x_{5}+a_{6} \cdot$ $\mathrm{x}_{6}+\mathrm{a}_{7} \cdot \mathrm{x}_{7}$

Dimana :

$\mathrm{Y}=$ debit banjir $\left(\mathrm{m}^{3} / \mathrm{det}\right)$

$\mathrm{X}_{1}=$ Luas Kopi (Ha)

$\mathrm{X}_{2}=$ Luas Semak Belukar (Ha)

$\mathrm{X}_{3}=$ Luas Kebun Campuran (Ha)

$\mathrm{X}_{4}=$ Luas Sawah $(\mathrm{Ha})$

$\mathrm{X}_{5}=$ Luas Perkebunan Besar (Ha)

$\mathrm{X}_{6}=$ Luas Perkebunan Rakyat (Ha)

$\mathrm{X}_{7}=$ Luas Permukiman $(\mathrm{Ha})$

Tabel 6. Debit banjir dan perubahan tata guna lahan 


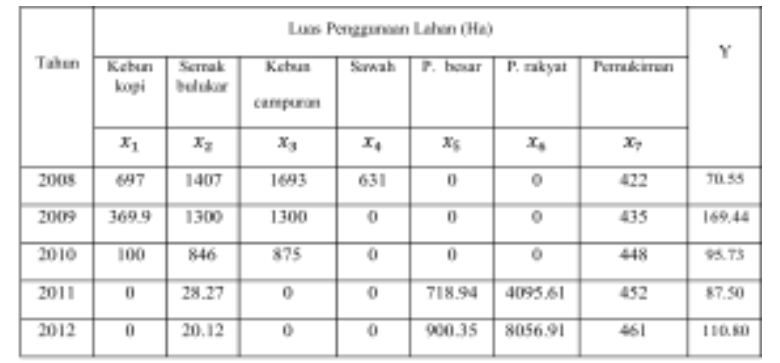

Berdasarkan hasil program SPSS yaitu analisis data yang dilakukan pada DAS sub DAS Musi Hulu Spas Kungku dengan menggunakan program SPSS maka terlihat bahwa perubahan tutupan lahan sangat mempengaruhi debit banjir pada periode ulang kala tertentu. Jumlah debit puncak yang terjadi pada kala ulang 2 tahun adalah = $12.23 \mathrm{~m}^{3} /$ detik, 5 tahun $=16.63 \mathrm{~m}^{3} /$ detik, 10 tahun $=20.56 \mathrm{~m}^{3} /$ detik, 25 tahun $=26.89 \mathrm{~m}^{3} /$ detik, 50 tahun $=32.75 \mathrm{~m}^{3} /$ detik dan pada 100 tahun $=$ $39.75 \mathrm{~m}^{3} /$ detik.

\section{Kesimpulan dan Saran}

\section{Kesimpulan}

Berdasarkan hasil penelitian tentang perubahan tutupan lahan terhadap debit banjir menggunakan model regresi linier berganda dengan variable bebasnya adalah tutupan lahan kebun kopi, semak belukar, kebun campuran, sawah, perkebunan rakyat, perkebunan besar dan pemukiman. Sedangkan variable tidak bebasnya adalah debit banjir yang terjadi akibat perubahan tutupan lahan. Berdasarkan hasil analisis data yang dilakukan pada Sub DAS Musi Hulu Spas Kungku Kabupaten Musi Rawas dengan menggunakan program SPSS maka terlihat bahwa perubahan tutupan lahan sangat mempengaruhi debit banjir pada periode ulang kala tertentu. Jumlah debit puncak yang terjadi pada kala ulang 2 tahun $=12.23 \mathrm{~m}^{3} /$ detik, 5 tahun $=16.63$ $\mathrm{m}^{3} /$ detik, 10 tahun $=20.56 \mathrm{~m}^{3} /$ detik, 25 tahun $=$ $26.89 \mathrm{~m}^{3} /$ detik, 50 tahun $=32.75 \mathrm{~m}^{3} /$ detik dan pada 100 tahun $=39.75 \mathrm{~m}^{3} /$ detik.

\subsection{Saran}

Berdasarkan hasil pengolahan data dengan SPSS maka masih terlihat ada beberapa variable yang memiliki nilai korelasi kurang dari 0,8 sehingga disarankan untuk penelitian selanjutnya dilakukan kajian yang lebih mendalam tentang dampak perubahan tutupan lahan dengan time series data hujan yang lebih panjang.

\section{Daftar Pustaka}

1. DRPM UI. Ltd All Rights Reserved. 2012. Pusat Riset Perubahan Iklim (RCCC-UI). Jakarta. http://pusatriset.ui.ac.id/pusatriset/?page_id=70,pusat (diakses 29 Juli 2013).

2. Suroso dan Hery, A.S (2001)."Pengaruh Perubahan Tata Guna Lahan Terhadap Debit Banjir Daerah Aliran Sungai Banjaran”, Jurnal Ilmiah Unsoed, Purwokerto.

3. Asdak, C (1995). "Hidrologi dan Pengelolaan Daerah Aliran Sungai". Gadjah Mada University Press, Yogyakarta.

4. Azmeri., dan Busri, H, 2010. Analisis Pengaruh Lahan Terhadap Kelestarian Air DAS Kreung Meureude, staf pengajar pada Jurusan Teknik Sipil Fakultas Teknik Unsiyah, Banda Aceh.

5. BPDAS Musi, 2008. Monitoring dan Evaluasi Tata Air DAS Musi di Provinsi Sumatera Selatan, BPDAS Musi, Dirjen RLPS Kehutanan, Palembang.

6. BPDAS Musi, 2011. Petunjuk teknis Monev Tata Air DAS Musi, BPDAS Musi, Dirjen RLPS Kehutanan, Palembang.

7. Roestam, S dan Robert, J.K . 2010. Tata Ruang Air. Yogyakarta : Andi.

8. Simamora, P., 2008. Analisis Curah Hujan Untuk Pendugaan Debit Puncak Dengan Metode Rasional Pada DAS Bedagai. Skripsi. Fakultas Pertanian Unsu. Medan.

9. Triana, vivi, 2008. Pemanasan Global, staf pengajar PSIKM Fakultas Unand, Padang.

10. Untari, A., 2009. Studi Pengaruh Perubahan Tata Guna Lahan Terhadap Debit di DAS Citepus Kota Bandung. Mahasiswa Pascasarjana Fakultas Teknik dan Lingkungan Institut Teknologi Bandung. Bandung.

11. Wendika, D dan Soeryamassaeka, B, dkk. Pengaruh Perubahan Tata Guna Lahan Terhadap Besarnya Debit (Q) Pada Suatu Kawasan. Jurnal Teknik Sipil, Untan, Pontian 